\title{
Die belydenis in kerkregtelike verband in die Nederduitsch Hervormde Kerk van Afrika ${ }^{1}$
}

\author{
SJ BOTHA
}

\section{INLEIDING}

Sewentig jaar gelede het die sogenaamde Ruysch van Dugteren-saak heelwat beroering in die Nederduitsch Hervormde Kerk veroorsaak. Hierdie saak het in die Kerk die vraagstuk oor die funksionering van die belydenis in die kerkreg as norm van die prediking en norm en reël van die leer en die lewe in die Kerk, geaktualiseer. Vir die eerste keer het 'n predikant van die Kerk uitdruklik gedeeltes van die belydenis en leer van die Kerk verwerp en is die Kerk se standpunt oor die funksionering van die belydenis vir die eerste keer van binne die Kerk self uitgedaag. In die saak het ds MJ Goddefroy as die leidinggewende figuur en woordvoerder na vore getree om die kerklike optrede te lei en die standpunt van die Kerk te verwoord.

Dit was egter nie die eerste keer dat Goddefroy in hierdie verband vir die Kerk die koers aangedui en die Kerk se standpunt onder woorde gebring het nie. Trouens, reeds in $\mathbf{1 8 9 0}$ het hy die Kerk se standpunt verdedig toe die Kerk van buite aangeval en van geringskatting van die belydenis en van leervryheid beskuldig is. In beide gevalle het Goddefroy sy verdediging op skrif gestel ${ }^{2}$ en die beginselstandpunte wat hy ingeneem het is steeds die geldende in die Nederduitsch Hervormde Kerk. Sy standpuntinname moet egter gesien word teen die agtergrond van sy kerklike-teologiese posisie waarin duidelik na vore kom dat hy terug gegryp het op en aangesluit het by die Calvinisties-reformatoriese tradisie soos dit in Nederland beslag gekry het.

\section{ENKELE REFORMATORIESE BEGINSELS IN SAKE DIE BELYDENIS VAN DIE KERK}

1. Die Kerkhervorming het 'n aanmerklike uitbreiding van die belydenisskat van die kerk gebring. Dit is nogal merkwaardig aangesien die Reformatore, en dan veral Calvyn, voortdurend gemaan het dat nie ligtelik nuwe belydenisse opgestel moes word nie $^{3}$. Dat dit nogtans gebeur het, dui daarop dat die belydenisse uit nood gebore is:

"Die Nederlandse Geloofsbelydenis is gebore uit die nood 
van die bloedige vervolging van die protestantse geloof. Die Heidelbergse Kategismus dank sy ontstaan aan die nood van die kategese in die toe nog jong protestantisme. Die Dordtse Leerreëls het voortgekom uit die nood van kettery en dwaling binne die kerk"4.

Dit het gegaan om eksistensiële beslissings van die kerk om sy geloof daadwerklik te kan bely. Daarom was hierdie belydenisse nie bedoel om rasioneel en kunstig voorbereide dokumente te wees nie, maar wel geskrifte om die lewende geloof van die kerk tot uitdrukking te bring en daadwerklik te bely. Die kerk wou belydende kerk wees.

2. Volgens die Reformatore kon die kerklike belydenis niks anders wees as die gelowige se antwoord op Gods Woord soos dit in die Skrif gegee is nie. Daarom was die primêre eis vir 'n belydenis om gesag te hê, dat dit volgens of ooreenkomstig Gods Woord moes wees. In die tweede plek moes dit wel deur 'n gesaghebbende kerklike vergadering aanvaar wees. ${ }^{5}$. Die belydenis het dus bedoel om samevatting van die inhoud van die Skrif te wees, om so uit te spreek, te bely, wat die Skrif omtrent bepaalde sake leer. Die Skrif alleen het steeds as die enigste norm van wat die kerk mag glo en leer gegeld. Die Belydenis bly mensewoord en kan nooit bokant of selfs gelyk met die Skrif as Gods Woord, gestel word nie. Daarom was dit ondergeskik en voortdurend toetsbaar aan die Skrif.

3. Tog het die kerklike belydenisse vir die Reformatore ook daadwerklik gesag gehad ${ }^{6}$. Die Skrif was wel die norma normans of regula fidei met goddelike en daarom absolute gesag. Aan die ander kant was die kerklike belydenis die norma normata of regula doctrinae met betreklike gesag. Dit was weliswaar alleen 'n afgeleide en sekondêre gesag, 'n norma secundaria. Tog was dit 'n gesag wat gehoorsaam moes word. Die kerk was oortuig dat, onder die leiding van die Heilige Gees, bepaalde waarhede uit die Skrif in die belydenis as waarhede van God saamgevat is en dat dit as belydenis geglo en gehandhaaf moes word op grond van Gods Woord. Binne kerkregtelike verband het dit ingehou dat die kerk kan verwag dat al die lidmate en in die besonder die predikante, volkome met sy belydenis sou instem. Van die predikante is daarom verwag dat hulle die belydenis sou onderteken as waarborg vir die regte uitoefening van hulle amp ${ }^{7}$.

4. Reeds van vroeg af is in die Nederlandse Kerk van die predikante verwag om die belydenisskrifte van die Kerk te onderteken ${ }^{8}$. Mettertyd is die wyse waarop die belydenisskrifte deur die predikante onderteken moes word, deur 'n proponentsondertekeningsformule omlyn en gepresiseer. As klassieke ondertekenings- 
formule in die Nederlandse Kerk geld die een wat deur die Sinode van Dordt 1618-1619 opgestel is. Volgens dié formule het die proponent verklaar":

"... oprechtelick in goeder conscientie voor de Heere met dese onse onderteeckeninge, dat wij van herten gevoelen ende geloven, dat alle de articulen ende stucken der leere in deze Confessie ende Catechisme der gereformeerde Nederlantsche kercken begrepen ... in alles met Godts woort over een comen. Beloven derhalven dat wij de voorsseide leere neerstelick zullen leeren, ende getrouwelyde voorstaan ..."

Deur die belydenisse op die wyse te onderteken, het die ondertekenaar dit geaktualiseer. Daarmee word dit daadwerklik sy eie belydenis en nie maar net ' $n$ historiese dokument waarvan die ondertekening 'n blote formaliteit was nie. So verklaar hy vrywillig en sonder enige dwang dat die formuliere van enigheid die norm en reël van sy prediking en sy dienswerk sal wees. Van gewetensdwang of beperking van teologiese ondersoek en studie is hier nie sprake nie, want die proponent verklaar "... oprechtelick en in goeder conscientie voor den Heere" dat die formuliere van enigheid "in alles met Godts woort over een comen". Vrywillig verbind hy hom hier kontraktueel aan die kerk en gee hy sy woord om saam met die kerk en soos die kerk te bely. Daarmee gee hy dan die versekering dat sy prediking en dienswerk binne die grense van die leer, soos die formuliere van enigheid dit uitdruk, sal bly ${ }^{10}$.

5. Uit voorgaande kan nie afgelei word dat die belydenis op die wyse tog onfeilbaar verklaar is nie. Die toetsingsreg het steeds gebly, maar dan moes by moontlike besware 'n bepaalde prosedure gevolg word. By twyfel of beswaar teen enige artikel van die belydenis, het die reg bestaan om bywyse van ' $n$ gravamen ${ }^{11}$ die saak vir beoordeling aan die bevoegde vergadering van die ampte voor te lê. In so'n geval is die Skrif alleen die bron en die maatstaf waarmee die beswaar of twyfel beoordeel kan word. Sou die beswaarde hierdie prosedure nie volg nie, maar byvoorbeeld die inhoud en waarheid van die belydenis in die openbaar aanval, dan funksioneer die belydenis as norm en reël waarmee sy afwyking gemeet word. Laasgenoemde wyse van optrede is natuurlik kontrakbreuk en op sigself ' $n$ bewys dat die dienaar ongeskik is vir sy dienswerk:

"So lank as die Belydenisskrifte nie deur 'n gravamen bevraagteken word nie, bly dit die norm en die reël vir die prediking en die gesaghebbende aanduiding in die kerk van waar die grense van die kerk lê. Indien iemand oor daardie 
grens gaan, versteur hy die eenheid van die geloof en die eensgesindheid wat vir die kerk ontbeerlik is" ${ }^{\prime 2}$.

6. Behalwe die reg tot die indien van gravamina is daar ook nog in twee ander opsigte ruimte gelaat voordat tugmaatreëls in werking gekom het.

\subsection{Die erkenning van die "Libertas Prophetandie"}

Hierdie vryheid van profesie het betrekking gehad op die gebiede waaromtrent nie enige uitsprake in die belydenisse gemaak is nie. By die uitleg van die Heilige Skrif kan sulke sake soos profesië wat nog nie vervul is nie, chronologiese, topografiese, argitektoniese, genealogiese en filologies-teologiese kwessies in aanmerking kom $^{13}$. Fundamentele tekste, waaroor die kerk reeds uitsprake gemaak het, het hiervoor nie in aanmerking gekom nie. Hierdie vryheid kon in ruime mate beoefen word, mits daarvan nie misbruik gemaak word nie en steeds gehou word aan die reëls van die geloof. Dit moet erken word dat grense hier moeilik aan te wys is.

\subsection{Die Toleransie}

Hier was die bedoeling om die swakkeres en dwalendes tegemoet te kom. Dit het nie gespruit uit beginselloosheid nie, maar wou alleen rekening hou met die moontlikheid dat iemand, deur gebrek aan insig, deur invloed van buite of deur vooringenomenheid, maar tog eerlik en opreg, besware kon hê teen een of meer stukke van die leer. Hierdie dwalinge hoef dan nie goedgekeur of gehandhaaf te word nie, maar tydelik kon dit verdra en geduld word totdat dit mettertyd verbeter kon word ${ }^{14}$. Daar sou dus onderskei moes word of iemand vanweë' $n$ gebrek aan insig of uit onkunde gedwaal het en of hy bloot hardnekkig aan 'n bepaalde dwaallering vasgekleef het.

7. Laastens kan nog daarop gewys word dat die belydenis ook die grense van die kerk beskryf:

"In die vroeë kerk is die geloofsbelydenis gebruik om die grens te trek tussen gelowig en ongelowig, later bepaal dit die grens tussen die ortodokse geloof en kerk aan die een kant en die ketter of schismatikus aan die ander kant. In die tyd van die Kerkhervorming trek dit dit grense tussen die ware en die valse kerk, maar ook tussen ware kerk en ware kerk, soos in die geval van die Lutherse en Calvinistiese kerk"15. 


\section{GODDEFROY EN DIE BELYDENIS}

"Geen Christendom zonder Christus; geen Kerk zonder belijdenis; maar ook geen belijdenisschrift of formulier boven of nevens het onbedrieglijke Woord des Heeren"16.

Met hierdie antitetiese stelling, waarin hy hom duidelik na twee kante afgegrens het, het Goddefroy homself kerklik-teologies getipeer. Juis uit hierdie kort stelling blyk sy beskouing oor die verband tussen Skrif en belydenisskrif. Enersyds het hy duidelik standpunt ingeneem teenoor die teologiese modernisme van sy tyd deur die stel dat hy geen Christendom sonder Christus of kerk sonder belydenis kan aanvaar nie. Andersyds wou hy ook niks daarvan weet dat die Belydenisse van die kerk op onreformatoriese wyse, gelyk aan of bo die Heilige Skrif gestel word nie. In hierdie geval het hy stelling ingeneem teenoor die Neo-calvinisme van Abraham Kuyper waar die belydenis gemaak is tot "accoord van kerklijke gemeenskap" waardeur in die praktyk die belydenis eerste kom en die Skrif tweede $^{17}$. Die fokuspunt was vir Goddefroy dat die Heilige Skrif, die Woord van God, te alle tye absoluut normatief vir die kerk bly. Hy het ' $n$ baie skerp onderskeid gemaak tussen Skrif en belydenisskrif, Godswoord en mensewoord. Verder het hy as uitvloeisel hiervan die belydende karakter van die kerk sterk beklemtoon. Die kerk moes nie alleen 'n suiwere leer of 'n regsgeldige belydenisskrif hê nie, maar die kerk moes inderdaad bely wat in die belydenisskrif vasgestaan het.

Met hierdie kerklik-teologiese standpunt het Goddefroy aangesluit by die historiese standpunt van die Nederduitsch Hervormde Kerk wat belydende kerk en nie belydenis-kerk nie, wou wees. Goddefroy was egter by uitnemendheid die man wat geroep was en instaat was om hierdie standpunt te verwoord en in sy ampsbediening praktiese gestalte te gee.

1. Behalwe die twee geleenthede waar Goddefroy spesifiek geroep was om die Nederduitsch Hervormde Kerk se standpunt ten opsigte van die belydenisse te verdedig, kan ook ander voorbeelde aangehaal word waar sy gedagte in hierdie verband duidelik geblyk het. Hier word slegs na twee verwys ${ }^{18}$ :

1.1 In die reorganisasie van die Nederduitsch Hervormde Kerk na die mislukte kerkvereniging van 1885, het die Algemene Kerkvergadering van 1888 ook aandag gegee aan wysigings van die bestaande kerkwet, soos deur Goddefroy voorgestel. Die eerste wysiging, het betrekking gehad op artikel, van die Algemene Bepalingen van die kerkwet van 1869 wat soos volg gelui het: 
"De Nederduitsch Hervormde Kerk bestaat uit al die hervormde gemeenten in de Zuid-Afrikaansche Republiek. Hare belijdenis staat uitgedrukt in de volgende formule, de Nederduitsch Hervormde Kerk in de Zuid Afrikaansche Repubiek grond zich op de leer van de Bijbel, als Gods heilig Woord; de 37 Artikelen der Nederlandsche geloofsbelijdenis en de 5 Dordtsche leerregels, zooals de zijn vastgesteld in 1618 en 1619 te Dordrecht".

Goddefroy het dit as ' $n$ lompe formulering beskou en terselfdertyd wou hy die sweem van gelykstelling tussen die Woord van God en die menslike belydenisskrifte en formuliere, wat uit die bewoording afgelei kon word, verwyder. Sy tweërlei beswaar teen die oorspronklike artikel het hy soos volg verwoord:

"Vooreerst is dit minder juist om te zeggen, dat de belijdenis der Kerk in een formule staat uitgedrukt, terwijl deze belijdenis toch eigenlijk alleen hare uitdrukking vindt in de Formulieren van Enigheid der Ned. Herv. Kerk; ten andere is het niet aanbevelenswaardig te zeggen: de Kerk grond zich op de leer van den Bijbel, den Heidelbergschen Catechismus, de 37 Artikelen en de vijf Dordtsche leerregele, omdat zoodanige formulering aanleiding geeft om te denken aan gelijkstelling van Gods Woord met menschelijke Schriften, door ze als in een adem te noemen, en op een lijn te stellen als grondslag der kerk, hetgeen strijdig is met het Ned. Hervormde grondbeginsel neergelegd in Art. 7 van de Ned. Geloofsbelijdenis".

Daarom het hy 'n korter en duideliker formulering voorgestel:

"De Ned. Hervormde Kerk bestaat uit al de Hervormde Gemeenten in de Zuid Afrikaansche Republiek. Hare belijdenis grond zich op de Heilige Schriften als Gods Woord en staat uitgedrukt in de formulieren van eenigheid, zooals die zijn vastgesteld in 1618 en 1619 door de Nationale Sijnode te Dordrecht ${ }^{\prime \prime 19}$.

1.2 As tweede voorbeeld word verwys na nog 'n wysiging wat Goddefroy in 1888 aan die kerkwet voorgestel het en wat betrekking gehad het op die proponentsondertekeningsformule. Die wesenlike verskil van sy voorstel en die bestaande formule was daarin geleë dat voortaan nie van die kandidaat verwag sou word om 'n formule te onderteken 
"waarin hij belooft getrouw en oprecht de leer van de Ned. Hervormde Kerk te prediken".

maar wel dat hy 'n formule moes onderteken waar hy verklaar dat hy

"... oprechtelijk het Evangelie der Genade overeenkomstig Gods Woord en in overeenstemming met de formulieren der Ned. Hervormde Kerk, zooals die zijn vastgesteld door de Nationale Sijnode van Dordrecht in 1618 en 1619 te zullen prediken en leeren".

Dit was Goddefroy se oortuiging dat die predikant nie geroep is om ' $n$ kerkleer te verkondig nie, maar wel die evangelie van genade. Trouens, die predikant word evangeliedienaar en nie dienaar van 'n kerkleer genoem nie. Vir hom was dit daarom vanselfsprekend:

"Zoveel hooger also den Heeren Woord staat boven het woord zelfs van de uitnemendsten der menschen, zooveel hoger achten wij ook de roeping van den Evangeliedienaar, boven den dienaar eener kerkleer".

Dit het nie vir Goddefroy ingehou dat hy daarmee die gesag van die belydenis op enige wyse in gedrang wou bring of wou geringskat nie. Ongekwalifiseerd het hy steeds die standpunt van Dordt onderskryf

"dat de Evangeliedienaar geen andere leer zou voorstaan of verdedigen, dan de overeenstemt met de belijdenis der Kerk".

Daarom kon hy verklaar dat die dienaar van die Woord verplig was

"... zich by de verkondiging te houden aan de belijdenis der Kerk ..."

Die belydenis het vasgestaan en die predikant moes hom daaraan hou. Hoewel dit nie sy taak was om die kerkleer te verkondig nie, maar wel die evangelie ooreenkomstig Gods Woord, moes die verkondiging egter geskied in ooreenstemming met die belydenis van die kerk.

Uit die voorgaande twee voorbeelde is daar twee sake wat duidelik na vore kom in Goddefroy se denke. Eerstens is daar die skerp beklemtoning van die onderskeid tussen God se Woord en mensewoord en tweedens die beklemtoning van die belydende karakter 
van die kerk. Juis in laasgenoemde geval kom duidelik na vore dat sy gedagtes in lyn gelê het met dié van Hoedemaker wat ook swaar klem op die belydende karakter van die kerk gelê het:

"Wij verwachten heil niet van eene formule, maar van de Kerk die belijdt, niet heeft beleden, niet eeue rechtsgeldende belijdenis bezit, maar belijdt ${ }^{\prime 20}$.

\section{DIE KONTROVERS GODDEFROY-BOSMAN. 1888-189021}

Hier word nie weer op die hele kontrovers ingegaan nie, maar slegs die tersake aspekte word uitgelig. Ds HS Bosman het in sy aanvalle uitgegaan van die veronderstelling dat die Nederduitsch Hervormde Kerk en sy predikant, ds Goddefroy liberaal was, leervryheid voorgestaan het en die sogenaamde quatenus-standpunt in verband met die proponentsondertekeningsformule daarop nagehou het. In sy antwoord op die aanvalle toon Goddefroy baie duidelik aan dat, terwyl Bosman beweer dat dit vir hom gaan om die handhawing van die suiwere leer, daar by hom begripsverwarring bestaan het ten opsigte van wat die suiwere leer wel was en wat die verhouding tussen Heilige Skrif en belydenisskrif was.

Oor wat die suiwere leer sou wees het Bosman hom teenstrydig uitgelaat. Aan die een kant het hy wel, in ooreenstemming met die reformatoriese standpunt verklaar dat hy nie die belydenisskrifte bo of naas Gods Woord stel nie en dat hy ook nie die belydenisskrifte beskou as eensluidend met die volstrekte waarheid nie. Hierin kon Goddefroy met hom volkome saamstem.

Aan die ander kant kanselleer Bosman sy eie standpunt deur teenstellende uitsprake. Hy sê naamlik dat die suiwer leer is "de leer der vaderen omdat die ook is de leer des Bijbels". Vir Goddefroy was dit duidelik gelykstelling van menslike geskrif met Gods Woord. Goddefroy se argument was:

"... volgens Art 7 van de Ned. Geloofsbelijdenis mocht men geen menschelijke schriften ook maar vergelijken bij de Goddelijke Schriften. Niet alleen dat Ds B ze wel degelijk vergelijkt, maar hij stelt se volkomen op een lijn, zeggend: de leer der Vaderen is de leer des Bijbels.

Dit is een hoog ernstige dwaling, en een aanranding van de hoogheiligheid van het woord der Openbaring in de Schriften des O. en des N Testaments".

Goddefroy maak ook ernstig beswaar teen 'n ander uitspraak van Bosman naamlik:

“Duidelijker gesproken- ik versta de $\mathrm{H}$ Schrift in den zin 
waarin de gezuiverde kerk aller eeuwen, die verstond en dus overeenkomstig de 3 Formulieren van Enigheid".

So 'n uitspraak hou in dat die Skrif in die lig van die Formuliere van Enigheid uitgelê moet word. Goddefroy stel dit duidelik dat dit 'n totale oorskryding van die gesag van die belydenis is. Die funksie van die belydenis is om te sê wat in die Skrif gehoor is en nie andersom sodat na die Skrif geluister moet word om te hoor wat die belydenis sê nie.

Weer eens kom dit duidelik na vore: die mensewoord, die belydenisskrif, mag nie bo of naas God se Woord, die Skrif, gestel word nie. Dit beteken egter geensins dat die gesag van die belydenis nie erken en gehoorsaam moet word nie. Die predikant moes hom in sy prediking hou aan die belydenis en daarom moes hy die belydenis ook onderteken en dan quia onderteken want, verklaar Goddefroy,

“... het (is) voor mij ten alle tijde en ook nu nog een ongerijmdheid ... bij de ondertekening van de Formulieren eener Kerk te spreken van, of te denken aan een quatenus, waardoor de geheele ondertekening willekeurig wordt, en gelijk staat met nie ondertekening"11.

Die belydenisse het dus vir Goddefroy beslis bindende gesag gehad as die norm van die prediking en norm en reël vir die leer en die lewe in die kerk. Daarom het hy 'n voorwaardelike ondertekening van die belydenis ten enemale verwerp.

\section{GODDEFROY EN DIE RUYSCH VAN DUGTEREN-SAAK ${ }^{22}$}

Waar ds HS Bosman die Nederduitsch Hervormde Kerk en Goddefroy van buite die Kerk aangeval en van leervryheid en geringskatting van die belydenisse beskuldig het, daar het ds CJL Ruysch van Dugteren die Kerk van binne beskuldig van leerdwang en van oorskatting van die betekenis van die belydenis. Veral in die tweede geval het die vraag na die funksionering van die belydenis in kerkregtelike verband, sterk na vore gekom.

Die probeem van Van Dugteren was dat hy reeds by sy legitimasie oneerlik was. Hoewel hy reeds toe al sekere besware teen gedeeltes van die belydenisse gehad het, het hy tog sy handtekening onder die ondertekeningsformule geplaas en sodoende verklaar

"dat hij de leer, die in bovengenoemde formulieren vervat is, gelooft overeenkomstig Gods heilig Woord te zijn".

Hy het dit egter as ' $n$ formaliteit beskou wat hy moes deurgaan om tot predikant toegelaat te kon word. Hy het dus nie werklik 
kon verklaar dat hy die belydenisse onderskryf omdat dit in ooreenstemming met Gods Woord was nie. Dit kon dus ook nie daadwerklik sy eie belydenis wees wat hy vrywillig en sonder enige dwang as norm en reël van sy prediking en dienswerk aanvaar nie. Tog het hy dit onderteken, terwyl hy ongetwyfeld self deeglik besef het dat hy ' $n$ valse verklaring afgelê het. $\mathrm{Na}$ twee jaar het hierdie onware verhouding hom so beswaar dat hy besluit het om dit te erken.

Uit Van Dugteren se siening van sy posisie blyk die volgende:

3.1 Dat hy nie langer sy ondertekening van die belydenisse, omdat hulle ooreenkomstig God se Woord was, kon handhaaf nie.

3.2 Tog het hy gemeen om aan te bly as predikant omdat sy afwykende siening ten opsigte van die belydenisse na sy mening gering was.

Onder leiding van Goddefroy het die Kommissie van die Algemene Kerkvergadering, nadat Van Dugteren se saak verhoor is, tot die volgende uitspraak gekom:

1. Afwyking van enige deel van die leer van die Kerk, soos vervat in die Formuliere van Enigheid, is strydig met die belofte wat met die ondertekening van die proponentsondertekeningsformule bevestig is.

2. Geen leervryheid kan toegestaan word nie, aangesien dit sou lei tot ontbinding van die Kerk.

3. By eventuele besware teen die belydenis moes die korrekte voorgeskrewe kerkregtelike prosedure gevolg word.

4. Van Dugteren het opgehou om predikant te wees van die Kerk die oomblik toe hy sy handtekening teruggeneem het.

In 'n latere geskrif onder die titel Neen! Niet Roomsch!, verantwoord Goddefroy die beslissing van die Kommissie van die Algemene Kerkvergadering en gee hy ook volledig sy siening van die funksie van die belydenis in kerkregtelike verband binne die Nederduitsch Hervormde Kerk ${ }^{23}$.

In sy geskrif betoog Goddefroy eerstens dat Van Dugteren homself buite die bediening van die Woord in die Nederduitsch Hervormde Kerk geplaas het omdat hy sy handtekening onder die legitimasieformule teruggetrek het. Daarmee het hy sy kontraktuele binding van die Nederduitsch Hervormde Kerk om die Kerklike wette en belydenisskrifte te aanvaar en te gehoorsaam, verbreek. Goddefroy beroep hom op Dordt en betoog dat, hoewel die predikante in die Nederduitsch Hervormde Kerk nie in soveel woorde dieselfde legitimasieformule onderteken het nie, die beginsel steeds die van Dordt is. Daarom kon nie toegelaat word dat die predikant oor die belydenis van die Kerk tegelyk ja en nee sê nie en dat hy die toetsingsreg in 
eie hand sou neem en dan teen sy eie onderneming sou ingaan nie. Om sy standpunt nog nader te substansieer verwys Goddefroy na artikel 53 van die Post-acta van die Dordtse Sinode:

"... dat menschen die b.v. het toetsingsrecht van de Kerk, in eigen handen zouden willen nemen, zich zelf moeten verbinden, om indien zij tegen hun handteekening machten handelen, door de eigen daad (ipso facto) gesuspendeerd zouden zijn van hunne diensten".

In die legitimasieformule is die wyse van ondertekening gepresiseer en daarvolgens het die belydenisse die funksie om norm van die prediking en norm en reël van die leer en lewe in die kerk te wees. Daaraan moes die predikant gehou word anders sou "tegen de wet en de constitutie der kerk in" gehandel word en dit sou tot gevolg hê:

"... feitelijke een vrijbrief uittereiken - aan wie dan ook waardoor van de Kerkgemeenskap word gemaakt: een soort 'Nut van 't algemeen'; een 'Band van los en vast'; een lieftallig 'Allegaartje'".

Tweedens toon Goddefroy aan wat die verskil in standpunt tussen die Roomse en die Protestantse kerk oor die belydenis is. By Rome is die Pous, as opvolger van Petrus en plaasvervanger van Christus, die een wat in geloofs- en gewetensake eenvoudig gebied en sy uitsprake moet as onfeilbaar aanvaar word. Daar is sprake van gewetensdwang.

By die Protestante is die Woord van God die enigste rigsnoer in sake van geloof en lewe. Menslike gesag kan nie die gewete dwing nie. Daarom is die belydenisskrifte in die Protestantse kerke altyd toetsbaar aan die Skrif alleen. Maar dit beteken nie dat die belydenis in Protestantse kring so gerelativeer is dat elke lidmaat en elke predikant dit na willekeur kon uitlê nie. Daarom kan die toetsingsreg nie maar ordeloos geskied nie, maar bestaan daaromtrent bepaalde voorskrifte. Ook in Protestantse kring is geloofseenheid verlang en daarom geld die eis

"Onderwerping aan de Belijdenis der Kerk omdat zij Bijbelsch, onderwerping aan de Bijbel omdat deze goddelijke is".

Die toetsingsreg mag nie met "teugelloze vrijheid" verwar word nie.

Voortvloeiend hieruit beoog Goddefroy dan derdens dat elke lidmaat en predikant gebonde is aan sy eie belydenis en belofte. Hy stel dit so:

“Tegenover 'Kerkgezag en gewetensdwang' van Rome stellen 
de kerken der Hervorming 'gebondenheid aan eigen Belijdenis en Belofte'.

Is dit zoo onredelijk?

Waar Rome gezag uitoefent over de gewetens der menschen; haar Belijdenis van boven af oplegt en decreteert; en die Belijdenis desnoods te vuur en te zwaard op de keel drukt harer leden! daar vraagt de Hervormde Kerk niets anders (niets meer, maar ook niets minder!) dan eerlijke uitvoering van eigen belofte en kontrakt, gemaakt ten aanzien van de uitdrukking van het geloof der gemeenschap, neergelegd in de Formulieren; opgemaakt door de wettige daartoe verkozen vertegenwoordigers der gemeente".

Hierdie argument van Goddefroy veronderstel absolute eerlikheid by die ondertekening van die legitimasieformule. Wie teken maak die belydenis van die kerk sy eie belydenis wat hy van harte wil bely. Wie nie van harte (= quia) kan teken nie durf nie teken nie. Want ' $n$ voorwaardelike ondertekening van die formule is eenvoudig onsin. Dit is netso goed as om nie te teken nie. Wie egter geteken het durf nooit met die belydenis na willekeur omgaan met die houding:

"... ik zal deze in de Kerk; van den Kansel en overal waar het mij behaagt; behandelen, verklaren en uitleggen, naar eigen meening, inzicht en goeddunken! ' $I k$ ' de regel. ' $l k$ ' de onfeilbare! ' $l k$ ' de souvereine Macht!

... Dat nooit!"

Wie eerlik vrywillig en van harte geteken het, is gebonde en verplig om by sy eie belofte en belydenis te bly. Alleen so kan die kerk gebou word.

In die vierde plek betoog Goddefroy dat Van Dugteren se siening dat sy afwyking van die leer van die Kerk, soos in die Formuliere van Enigheid uitgedruk in verband met die uitverkiesing, maar van geringe betekenis was, nie korrek is nie. Die leer van die uitverkiesing was immers deur die opstellers van die belydenis as die hart van die kerk beskou. Wie aan die leer van die uitverkiesing raak, peuter met die hart van die kerk en dit is nie so gering dat dit maar verdra kan word nie. Om agter argumente te skuil van "geringe afwijking", "niet volkomen instemmen" en "minimum van verschil" en dan tog die "cor ecclesia" aan te tas deur ' $n$ "reservatio mentalis" daarop na te hou is bedenklik en oneerlik. Om voortdurend die woord "volkome" te gebruik is 'n misleiding want dit word nêrens beweer dat die kerklike belydenisskrifte volmaak is nie: 
“er zijn geen 'volkomen' Belijdenisschriften, en aan onze zijde is nimmer 'volkomen' werk".

Maar die woord word ook nie in die legitimasie formule gebruik nie. ${ }^{24}$.

Verdraagsaamheid moet daar wel in die kerk wees teenoor andersdenkendes:

“... vooral ook omdat iedere 'Belijdenis' voor ons is: een volkomen uitdrukking van het geloof der Gemeente; welke zeer zeker een gedurige Bijbeldoop van noode heeft ..."

As die hart van die kerk aangetas word dan is die grense van die kerk, soos in die belydenis beskryf, oorskry en dan het diegene wat hulle daaraan besondig het, hulleself buite die kerk geplaas.

\section{SLOTOPMERKING}

Ds Goddefroy het ongetwyfeld 'n belangrike bydrae gelewer om die Calvinistiese reformatoriese tradisie ten opsigte van die funksie van die belydenis in kerkregtelike verband in die Nederduitsch Hervormde Kerk te bewaar en te bestendig. By die nagaan van die geldende kerkwet is dit duidelik dat die funksie van die belydenis in die verband steeds gesien word in die koers wat deur hom aangedui is. Daar is steeds die skerp beklemtoning van die belydende karakter van die kerk wat in die woorde van die aanvaarde belydenis daadwerklik sy geloof wil bely en nie maar net daarop wil roem dat hy 'n suiwere leer en regsgeldige belydenis het nie $e^{25}$. Dit veronderstel dan ook dat die legitimasieformule nie in ' $n$ blote formaliteit as ' $n$ historiese dokument onderteken word nie. Die ondertekenaar aktualiseer die belydenis en stem daarmee in dat dit inderdaad uitdrukking van sy eie geloof op grond van God se Woord is. Daarmee verbind hy hom kontraktueel daaraan dat die belydenis as norm en reël vir sy prediking sal geld, as grens wat hy nie sal oorskry nie.

Gelyktydig word daar egter steeds op voetspoor van Goddefroy, in die kerkwet skerp onderskei tussen Skrif en belydenisskrif, God se Woord en mensewoord ${ }^{26}$. Dit het ongetwyfeld daartoe bygedra dat die belydenis nog nooit in die Nederduitsch Hervormde Kerk verabsoluteer geraak het en die siening van die funksie daarvan in blote juridiese sin gestagneer het nie. Terwyl die normatiewe funksie erken en gehandhaaf word, geskied die erkenning en handhawing altyd onder die besef dat die belydenis steeds "norma normata" is en nie "norma normans" nie. Daarom het die belydenis ook nog nooit in die Nederduitsch Hervormde Kerk gefunksioneer in die gees van 'n maatstaf en stok waarmee doelbewus na ketters gesoek 
moet word wat uit die Kerk uitgedryf moet word nie. Die teologiese ondersoek en studie in die Kerk is nog nooit beperk met 'n beroep op die belydenisskrifte nie. Die toetsingsreg word steeds gehandhaaf maar dan met die uitdruklike veronderstelling dat enige moontlike teenstellende resultate deur middel van 'n gravamen aan bevoegde kerklike regeerliggame voorgelê sal word ${ }^{26}$.

Dit alles beteken wel dat die Kerk steeds van al sy lidmate en predikante kan verwag dat met verantwoordelikheid en respek met die belydenisskrifte omgegaan sal word!

\section{Aantekeninge}

1. Lesings gehou voor die Kongres van die Kerkhistoriese genootskap van die Nederduitsch Hervormde kerk op 17 November 1981.

2. Die twee publikasies was onderskeidelik De Kerkkwestie niet een Leer-maar een Levenskwestie, 's-Fravenhage 1890 en Neen niet Roomsch!, Pretoria 1912.

3. Sien J Plomp: De Kerkelijke Tucht Bij Calvijn, Kampen 1969, bl 256.

4. II de Wet: 'n Nuwe Belydenis as "Akkoord van gemeenskap" tussen die Drie Afrikaanse Kerke - Is ' $n$ nuwe belydenisskrif moontlik en nodig? artikel in die Jaarblad 1973 van die Van der Hoff Teologiesevereniging, bl 41.

5. AD Pont: Die Historiese Agtergronde van ons Kerklike Reg, Pretoria-Kaapstad 1981, bl 239.

6. AD Pont aw, bl 240, H Bouwman: De Kerkelijke Tucht, Kampen 1912, bl 187.

7. J Plomp: aw, bl 257.

8. Vir'n kort geskiedenis van die Ondertekeningsformule vgl H Bouwman: Gereformeerde Kerkrecht, Tweede Deel, Kampen 1934, bl 566 vv en ook AD Pont: aw, bl 241.

9. Aangehaal by H Bouwman: Gereformeerde Kerkrecht, bl 572.

10. AD Pont: aw, bl 242.

11. H Bouwman: Kerkelijke Tucht, bl 188.

12. AD Pont: aw, bl 243.

13. H Bouwman: aw, bl 189.

14. H Bouwman: aw, bl 191-192.

15. AD Pont: aw, bl 240.

16. Sien SJ Botha: Ds Marie Joseph Goddefroy (1848-1920). Sy Lewe en Betekenis, Pretoria, 1981, bl 58.

17. Vgl oor die Neo-Calvinisme se siening van die belydenisskrifte as "accoord van kerkelijke gemeenskap". SP Engelbrecht: Neo-Calvinisme Ontwikkeling en afwyking. Pretoria - Kaapstad, 1945, bl 7 vv en bl 20 vv.

18. Die gegewens rondom hierdie twee voorbeelde is geneem uit S] Botha: aw, bl 65-67 en bl 68-69.

19. 'n Vergelyking tussen Goddefroy se voorstel en die huidige artikel 1 van die Kerkwet van 1979 toon duidelik die invloed van Goddefroy. Dit lui so:

"I Die Kerk

"Die Nederduitsch Hervormde Kerk van Afrika grond hom op die Bybel as Woord van God. Ooreenkomstig sy belydenis is die Kerk openbaring van die een heilige, algemene Christelike Kerk. Sy belydenis word uitgedruk in die formuliere van eenheid, naamlik die Nederlandse Geloofsbelydenis, die Heidelbergse Kategismus en die Dordtse Leereëls in 1618 en 1619 in Dordrecht vasgestel".

20. PH J Hoedemaker: De Gereformeerde Kerk, $185 \mathrm{Nr} 340$, aangehaal by GR PH Scheers: Philippus Jacobus Hoedemaker, Wageringen 1939, bl 206.

21. Op hierdie kontrovers is volledig ingegaan in ' $n$ vorige lesing wat ook voor die 
kongres van die Kerkhistoriese Genootskap gehou is en gepubliseer is in Hervormde Teologiese Studies, Jaargang 33, Afl 3 en 4 bl 41-57 onder die titel: Waar lêt die wortels van die "sondige verscheurdheid" in die Kontrovers Bosman-Goddefroy 1888, 1890, sien ook verder SJ Botha: Ds Marië Joseph Goddefroy 1848-1920, Bl 84 vv.

22. Vanuit' $n$ ietwat ander boek is reeds op hierdie saak ingegaan op die kongres van die Kerkhistorise Genootskap van 11 November 1980 onder die titel: De Nederduitsch Hervormde Kerk en Leeroryheid uit die Geskiedenis van die Nederduitsch Hervormde Gemeente Pretoria. Hierdie artikel is tans ter perse vir publikasie in die Hervormde Teologiese Studies. Vgl ook SJ Botha: Ds Marié Joseph Goddefroy $1848-1920$, bl 200-209.

23. Goddefroy se geskrif was in reaksie op 'n brosjure van 'n bekwame juris dr HDJ Bodenstein: "Schorsing van Ds Ruysch van Dugteren: Word de Hervormde Kerk Roomsch!" Potchefstroom 1911, waarin hy 'n skerp aanval op die Nederduitsch Hervormde Kerk gemaak het en die Kerk beskuldig het van Roomse leerdwang en gewetensbinding!

24. Dit is interessant dat die woord "volkome" wel in die Kerkwet van 1979 Bepaling 73 voorkom terwyl dit in nie een van die vorige uitgawes gebruik is nie. Die Kerkwet is die Algemene Kerkvergadering van 1979 taalkundig hersien.

25. Uit artikel 1, IX en XI is dit wel duidelik. Bowendien het die Kerk al meermale verklaar dat hy 'n Christusbelydende Volkskerk wil wees. Sien byvoorbeeld SJ Botha: Die Volkskerk, Pretoria, 1972.

26. Artikel I gee hieraan duidelik uitdrukking.

27. Sien Bepaling 75. 